\title{
DOI: 10.1515/orga-2016-0006

\section{The Employee as the Unknown Actor? A Discourse Analysis of the Employee Share Ownership Debate with Special Emphasis on Central and Eastern Europe ${ }^{1}$}

\author{
Olaf Kranz ${ }^{1}$, Thomas Steger ${ }^{1}$, Ronald Hartz ${ }^{2}$ \\ ${ }^{1}$ University of Regensburg, Faculty of Business, Economics and Management Information Systems, Germany \\ olaf.kranz@ur.de, thomas.steger@ur.de \\ ${ }^{2}$ Independent researcher, Germany \\ ronald.hartz@wirtschaft.tu-chemnitz.de
}

\begin{abstract}
Background and purpose: Although employee share ownership (ESO) deserves of a long tradition, we still know little about employees' perspectives about ESO. The lack of knowledge about the employees' attitudes towards ESO is discursively filled in the ESO debate. This paper challenges that deficit by carrying out a semantic analysis of the literature with the aim to identify the various actor constructions used implicitly in the ESO discourse.

Design/Methodology/Approach: We conduct a semantic analysis of the ESO discourse. To unfold the order of this discourse we draw on the distinction between surface and underlying structure of communication in the sense of Michel Foucault. We interpret some semantic lead differences, a term coined by Niklas Luhmann, to constitute the underlying structure of communication.

Results: We can identify six different streams on the ESO discourse's surface level each defined by the ends pursued. The discourse's underlying structure is made up of the distinctions production-consumption, capital-labour, and ownership-control that also determine the actor models implicitly in use.

Conclusion: We can identify five different actor models implicit in the ESO discourse. While the CEE discourse differs on the surface level in as far as it is more concerned with questions of political legitimation of the privatisation process than with questions of economic efficiency, thus introducing political distinctions in the discourse rather missing in the west, it shares the underlying semantic lead differences with the Western discourse as well as the actor models anchored in those differences.
\end{abstract}

Keywords: Employee Share Ownership, discourse analysis, semantic lead distinctions, actor constructions, CEE countries

\section{The employee as discursive object in the debate about Employee Share Ownership}

We have been witnessing an ever growing discourse about Employee Share Ownership (ESO) on a worldwide scale over at least the last sixty years. From this discursive attention we can derive a general interest to transform individuals (e.g. Pierce and Rogers, 2004; Liu et al., 2009), companies (e.g. Poutsma, 2001; Mygind, 2002), or whole societies (e.g. Poutsma et al., 2003; Köhler, 2007) with the support of ESO. The very same discourse about ESO has

\footnotetext{
${ }^{1}$ Invited paper
} 
only recently come to observe and describe a severe lack of knowledge about the attitudes and the behaviour of the employee itself which features as the main actor in the discourse: "(E)mployee attitudes towards employee share ownership (ESO) is not very well researched and most research take a rosy view of these attitudes“ (Poutsma and Rondeel, 2006: 22). This claim is substantiated by the fact that (a) empirical studies directly addressing employees' perspectives about ESO are still scarce, (b) the existing studies concentrate on a limited number of companies explored by highly standardised questionnaire surveys (Hofmann et al., 1993; Hardes and Wickert ,2004; Kruse et al., 2008), and (c) several authors prefer to catch the topic by addressing distinctive experts speaking on behalf of employees (e.g. unionists, members of works councils) (Armstrong, 1982; Bispinck and Brehmer, 2008). In consequence, the ESO discourse gives the impression that the voice and perspective of employees is rather unknown or underrepresented and that the employee himself/herself seems to remain the "unknown actor" in the ESO field.

However, since the central topic in the ESO discourse is the transformation of the employee or its instrumentalisation for the transformation of companies or states, and since any ESO program rests on assumptions about employees' attitudes and behaviour toward ESO, the knowledge gap about the employee is discursively filled. In fact, the ESO discourse is rather speaking about the employee thereby constructing the employee as an actor. Empirically, the main narrator positions in the ESO discourse are filled by entrepreneurs and employers or their associations, unionists, politicians or legislators, and scientists. Those narrators tell us different narrations about ESO from their different perspectives, thereby constructing different models of 'the employee' as an actor, with each model containing the attribution of different essential characteristics to 'the employee' like values, attitudes, preferences, and behavioural tendencies. Thus, we can state that although there are claims about a knowledge gap about the employees' perspective on ESO, the very same discourse is continuously constructing a rich knowledge about those employees' view at the same time.

The knowledge gap about how employees perceive ESO also exists regarding the former socialist countries of CEE. For several reasons it is of particular interest to address this deficit here: (1) Employees in CEE bear a particular heritage regarding ESO due to the ideological form of common ownership that had existed during socialist times (Steger and Šrein, 2006). Those experiences may also influence their attitudes towards ESO since 1990 (Vickerstaff and Thirkell, 2000; Edwards and Lawrence, 2000). (2) After the fall of the Berlin Wall, CEE constituted a kind of vacuum and a field for experiments. The transfers of Western ideas, concepts and experts have been crucial for the transformation process in almost all CEE countries. Among them various forms of ESO schemes figured prominently but also several ideas and concepts countering employee ownership (Pollert, 1999; Dobák and Steger, 2003) which, taken together, often caused some ambiguous and unintended consequences. (3) Although neo-liberal ideas, concepts and proponents who are usually reluctant against ESO often dominated the transformation processes (Boycko et al., 1996; World Bank, 1996), ESO turned out to be an important political instrument in many CEE countries to get the privatisation process started (Earle and Estrin, 1996; Aghion and Blanchard, 1998). This raises the question about the rationales and constructions standing behind those activities. (4) While ESO played an important role in the early years of privatisation in CEE (Bogetic, 1993) a continuous decline must be witnessed since then (Kalmi, 2003; Mygind, 2012; Vaughan-Whitehead, 2003). Since the ESO programs in CEE ascribed an active role to the employees as actors capable of individual decisions, we certainly need to ask about the reasons for these developments as well as the employees' role. However, given the knowledge gap about the employee in the ESO debate that is bridged by discursively constructed actor models, we should also ask about the underlying logics of the different actor models and their role in the discourse. After all, the factual ESO programs implemented in the CEE context that formed the framework for the employees' individual decisions about share ownership had been influenced by the underlying assumptions about 'the employee' which, in turn, were shaped by the discourse at the same time.

These observations, together with the transformational power attributed to ESO, make the ESO discourse an extraordinarily appropriate object for an inquiry into the matter of how employees in particular and how economic actors in general are constructed in discourses. This paper challenges the described deficit by carrying out a semantic analysis of a substantial portion of respective literature, both from academics and practice, in order to identify and to describe the order of the discourse about ESO in general, and to unravel and reconstruct the construction of the employee as an actor by a discursive knowledge in particular. Because of the knowledge transfer from the West to the East during the transformation period, we treat the debate about ESO in CEE as part of a more general (Western) discourse. Nevertheless, we can identify rather different development paths regarding ESO between the Western industrialized world and the CEE countries (Kalmi, 2003) on the one hand and within the CEE countries on the other hand. While ESO is widespread in Slovenia (Mišić, 1998; Prasnikar and Gregoric, 2002) or the Baltic states (Kalmi, 2003), those models are rare in countries such as the Czech Republic or the former GDR (Steger and Šrein, 2006).

Our reconstruction highlights six main discourse streams about ESO. They will be described and critically discussed hereafter. Through this process different actor 
constructions of the employee together with some semantic lead differences become more salient. Specific attention to CEE countries will be paid by illustrating our results, where possible, with some distinctive material concerned with those countries, thereby highlighting the particular characteristics of ESO in CEE countries. The CEE debate regarding $\mathrm{ESO}$, we find, is more concerned with questions of political legitimation of the privatisation process than with questions of economic efficiency, thus introducing political distinctions in the discourse rather missing in the West.

Our paper proceeds as follows: We start by explaining our heuristic framework, the methodology and the overall research design' (section 2). Then, we outline six discourse streams that are determined by their stated ends that also affect which actor models of the employee, which effects and which implementation problems connected with ESO are perceived in the discourse (section 3). A discussion to summarise our main findings will round up the paper (section 4).

\section{Conceptual Frame, Methodology and Research Design}

To unfold the order of the discourse about ESO we draw on the distinction between surface and underlying structure of communication in the sense of Michel Foucault's earlier work on the birth of the clinic (1973). There, Foucault points out, that while on the surface of the communication intentions etc. may play a role, it is the underlying distinction between 'healthy' and 'ill' that organizes the medical discourse and enables a new way of medical perception.

Accordingly, on the 'surface' of the ESO discourse, a series of narrations can be identified. As it will be discussed later, the ESO narratives are mainly defined by the ends that should be achieved with the help of the ESO (see also Pendleton et al., 1995). In each case they conclude a problematic actual situation as well as a target-situation. So, ESO becomes in each case a part of a transformation narration - be it on the level of the society, on the company level or on the level of the individual employee. Some specific actor constructions always go hand in hand with those actual and ought-to-be situations. This means that the employee itself may be considered to be the 'dramatis personae' to be transformed. Otherwise, the employee and his/her behaviour may be perceived a constant variable to be taken into account and to be consciously used for the transformation of nation states or companies through the introduction of ESO.

During our semantic analysis, it will become visible that the heterogeneous actor constructions of the ESO discourse are themselves anchored in some semantic lead distinctions (Luhmann 1989) of the economic sphere.
According to Luhmann, semantic lead distinctions constitute an underlying communicative structure that enables to limit the spectrum of meanings connectable to the (general) societal communication, thus preventing the meaning from becoming fuzzy. For the economic discourse, for example, important semantic lead distinctions include production-consumption, capital-labour, and ownershipcontrol which can be empirically identified in the field. They relate to some economic actor constructions producer-consumer, capitalist-labourer (or employeremployee), owner-controller (or shareholder-manager) - that structure the discourse streams. Different discourse streams on the surface may choose from the supply of actor constructions rooted in semantic lead distinctions of the field and, subsequently, connect those actors with a fitting psychic background (e.g., motives, preferences, attitudes, intentions) as well as with the means to realize those intentions.

On balance, the logic of our methodological assumption is as follows: The empirical narrators (employers, politicians, unionists, etc.) pursue different ends by introducing or propagating ESO. Those different ends for ESO function as different narration motives within the discourse. The narration motives provide us with 'differentiae specificae' we can use in the discourse analysis to identify both different 'streams' at the surface level of the discourse and the corresponding actor models used within the streams to project the employee in a partial, yet distinctive way. Since the narration motives as well as the corresponding actor models are rooted in semantic lead distinctions we can draw conclusions from the motives and the actor models for the identification of the semantic lead distinctions and vice versa.

Our main interest lies on the ESO discourse's different constructions about 'the employee' which depend on different semantic lead distinctions and which are represented by different discourse streams more or less implicitly (cf. Figure 1). So, our main data is the discourse about ESO and our main research question regarding this discourse is: How are employees discursively constructed as economic actors by narration motives in the context of semantic lead distinctions within the ESO debate in general and with respect to the CEE region in particular?

The analysed text corpus consists of about 300 publications of scientific nature as well as from stakeholders (employers' associations, unions) and political parties. This synopsis of materials is based on the assumption that both the scientific and the public discourse refer to similar narrative elements, actor constructions, and semantic lead distinctions. While using a qualitative and iterative approach, we de-constructed and reconstructed the material in order to identify some distinguishable and intersubjectively valid discourse streams. This process was carried out until a state of saturation of the discourse streams was achieved. 


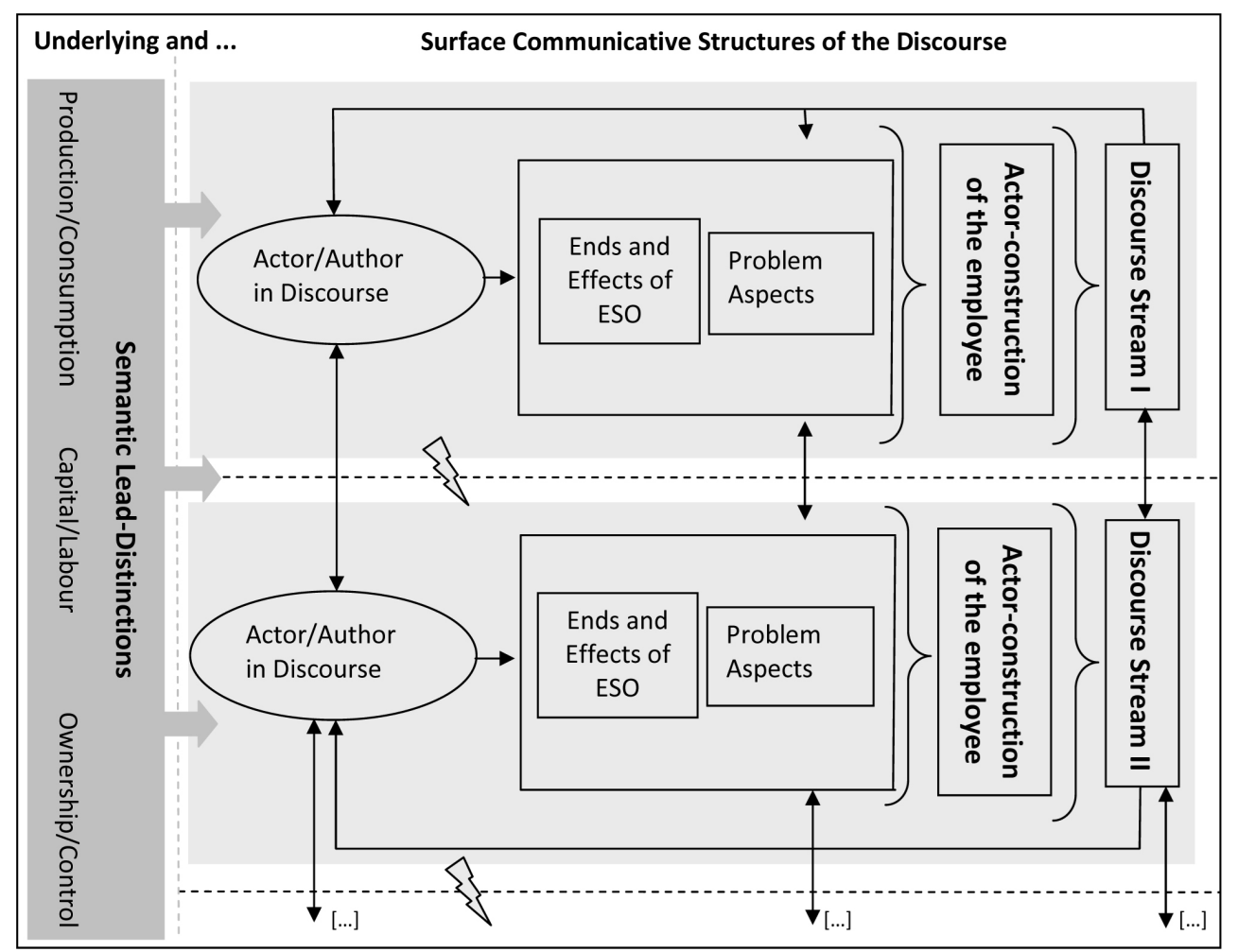

Figure 1: Analytical distinction and structural components of the literature review

This paper is built upon previous work by the authors (Hartz et al., 2009) and is developing further the argument made there with regard to the ESO discourse dedicated to the CEE region. For practical purposes, the data base used for the original analysis has been used for the actual analysis for a second time without making substantial changes to the text corpus. The rationale for this procedure is that the ESO discourse has been imported to the CEE region to a great extent and that the discourse has not been revived since. However, a substantial effort has been made during the interpretation phase of the empirical data for the current paper by focusing particularly on the special circumstances of the introduction of ESO in the CEE region as an instrument for mass privatization during the transformation period. Thus, the current paper is an application of the discourse model developed in the original paper, emphasizing its heuristic usefulness by extending its regional scope. With regard to our discourse model, particularly our idea is novel that semantic lead differences (Luhmann, 1989) substantiate Foucault's claim (1973) that there is a deep structure of communication underlying a discourse at the surface level of communication.

\section{The main streams and the dominant actor constructions of the employee in the ESO discourse}

\subsection{Beyond the capital-labour divide - ESO as a means to reconcile some antagonistic societal subgroups}

A first motive to be identified in the general discourse is the elimination of the conflict between capital and labour. In this context, ESO is propagated as a means to satisfy some different actual and potential needs that result from the capital-labour-conflict on the level of the society as well as on the level of the companies. Although some transformations of the society or the state are usually focused here, the employee as a specific actor construction is addressed too. Seemingly, the elimination of the capitallabour-conflict also requires a transformation of the employee, from a dependent waged labourer in deficit into a (positively connoted) co-owner and shareholder.

\section{Ends and assumed effects}

At first the discourse directly addresses the difference between capital and labour which also includes a series of further objectives and outcomes. In order to eliminate this 
conflict it is postulated to share the companies' profits with the employees and to improve the employees' influence (e.g., Fiedler-Winter, 2000; Wagner, 2002). It is interesting to note that the capital-labour conflict is perceived to be an 'ideology of the past' (Maier-Mannhart, 1996) that, nevertheless and contradictory, must still be overcome now. This is usually illustrated by numerous success stories of partnership models in companies (e.g. FiedlerWinter, 2000) that should help to contribute plausibility to the overall narration and even includes some voices from the employee side (e.g. Schuler and Wolff, 2001).

Another important point of reference is the unequal distribution of the national income. In this context ESO is perceived as a means to close or to limit this income divide and, thus, to make a contribution against the split of the society with respect to the capital-labour-conflict. Even the German unions agree on that since the divide of net incomes seems not to be repairable by wage increases alone (Kauls, 2006).

Other authors deal with the lead distinction of capital and labour too, although they stress some different aspects of it. Gaugler (2001) for instance refers to the importance of ESO as a means to guarantee human dignity in the economic context and to stabilise the free economic and social system. Hofmann and Munz (2002) even see the potential to overcome the conflict between insider and outsider since ESO may compensate the insiders for being prudent with respect to wage increases while it increases the employment chances of outsiders. Moreover, other European countries are interested in job security as well as in the integrative potentials provided by agreements between the social partners (Pendleton and Poutsma, 2004). The well known PEPPER program initiative of the European Commission can be considered closely in line with this (Poutsma et al., 1999).

\section{Counter arguments inside the discourse}

The idea to reconcile capital and labour is considered problematic from different perspectives. Several authors argue that ESO would neither be a panacea nor a useful instrument to eliminate this conflict since the assumed causality would be too less differentiated and, thus, not robust enough to hold out against critical questions.

Schätzle (1996) considers this idea as merely social romanticism while reality would go straight ahead to become a shareholder society. As a consequence, the rational employees would rather pursue their own private interests far from any reconciliation ideology. Poutsma and de Nijs (2003) mention several conflicts linked with different forms of participation. While financial participation would support diversity and flexibility of remunerations, some indirect forms of participation would foster collectivism, solidarity and justice. Consequently, the idea of 'reconciliation' would need to be connected to immaterial participation too. Gaugler (2001) and Blettner et al. (1995) identify some diverse societal trends, namely increasing hedonism, consumption behaviour, reservations against the economy, that continuously endanger the idea of 'partnership instead of class conflict'.

Hofmann and Munz (2002) state that employees' portfolio is already dominated by human capital. Thus, ESO would imply a double risk and a negative correlation of risk characteristics. This point is also made by union representatives (e.g., Huber, 2006; Kauls, 2006). Moreover, most authors in this discourse stream almost exclusively refer to successful companies (Maier-Mannhart, 1996; Fiedler-Winter, 2000) while the risk of a total loss is widely masked out in the logic of reconciliation.

Collom (2003) generally doubts about the idea to harmonise the interests of capital and labour. Some radical forms of workplace democracy could even revitalise some traditional class conflicts since those forms are appreciated for different reasons by management and employees. Furthermore, active labourers who usually prefer some far reaching forms of workplace democracy would hardly be satisfied by the kind of democracy that management is ready to grant them.

Finally, Priewe (2007: 683f.) points to the lack of adequate analyses about the correlation between the introduction of ESO and the distribution of the net income. He criticises that "a re-distribution of the national income through profit sharing will be realistic only if the latter was granted on top, i.e. in addition. But exactly this is not the intention of the protagonists of profit sharing".

\section{Peculiarities regarding $C E E$}

Due to historical reasons the motive of mediation of the capital-labour-conflict can hardly be found in the CEE debate. It rather asked how to re-introduce the distinction between capital and labour into a context characterised by public ownership and by an ideology that presumes all citizens to be representatives of the labour side in an ongoing historical-political fight with the capital side.

Gurdon (1991) refers to the transforming countries of CEE to point out that ESO affects the balance between 'public' and 'private'. Accordingly, the privatisation experiences make clear that the acceptance of ESO would be dependent on societal values and attitudes, for instance towards private ownership or profit orientation. Thus, the mediation motive makes part of the CEE debate as well, however in a more indirect way. The implementation of private ownership has to pay attention to some wide spread beliefs among citizens about justice and legitimacy regarding economic participation that have been shaped during the socialist times.

In order to minimize ,socio-political resistance“" (Bogetic, 1993: 463) against the transformation of ownership structures, it was decided in many countries to grant each citizen (or at least a large fraction of them) the right to become a shareholder. Thus, the question 
whether one becomes a capitalist or rather remains on the labour side was transformed into a decision on the level of individuals (e.g. Bogetic, 1993; Jones and Mygind, 1999). Since the difference between capital and labour can be ascribed to deliberative individual decisions, the probability that future conflicts of interests between foreign investors and domestic workers are perceived as capital-labour conflicts may be reduced right from the beginning. This concept also highlights that the focus of the ESO debate in CEE lies on the level of society rather than on the level of companies or individuals.

\subsection{From co-worker to co-owner - ESO as a means to activate the employee as an entrepreneur}

The actor construction of the entrepreneur as well as the ethos of entrepreneurship takes an important role in the second discourse stream. Linking ESO to entrepreneurship does not only secure the communicative connectedness with the dominant economic-political discourse but also relates ESO to some (positively connoted) emancipation values such as autonomy, self-actualisation and selfdetermined labour (Bröckling, 2007). This implies the postulate for a transformation of the employee from an assumingly passive subordinate into an active contributor.

\section{Ends and assumed effects}

First of all, ESO is intended to initiate a kind of entrepreneurial habitus among the participating employees - „from co-worker to co-entrepreneur“ (Maier-Mannhart, 1996). This should be achieved by linking some material sharing of profit or capital to ,the needed freedom for the activities of a co-entrepreneur" (Schneider, 1996: 112). So, ESO should include orientation both for accomplishment and for profit.

The entrepreneurial habitus also implies the idea of the entrepreneurial risk: "The greater the risk for the single employee the more sustainable is his/her change of behaviour" (Lezius, 2004: 24). A further aspect to be promoted by ESO is the idea of 'empowerment', i.e. "a change of thinking of the participants" (Pfüller, 2003: 28) leading to an increase of entrepreneurial engagement.

Moreover, the entrepreneurial habitus should be connected with a series of 'entrepreneurial virtues' that all together will result in some positive effects regarding productivity and competitiveness of the companies. Most prominently, the idea of 'psychological ownership' should lead to an improved organisational commitment as well as to a change of behavioural patterns such as diligence, loyalty or control and, in the end, to a positive impact on company performance (Pierce and Rodgers, 2004; Höge, 2006). Obviously, most authors perceive the 'entrepreneurial virtues' as a kind of secondary virtues that do not include questions about the control of the entrepreneurial processes. So, the employee remains on the side of 'labour'.

\section{Counter arguments inside the discourse}

Several authors question whether a change of behaviour in the sense of entrepreneurial habitus is realistic at all. Most often the share of capital on the employee side is very limited in relation to the total capital (Pendleton et al., 1998) and, consequently, the potential for control and participation in decision making does hardly exist (Blettner et al., 1995). Hammer and Stern (1980) found that the employees usually keep on regarding the management as the 'real' owners of the company and that they do not take any activity to change the internal power balance (similar Steger and Hartz, 2008). Van Dyne and Pearce (2004: 439) identified some positive effects of ESO on organisational commitment and pride, however their results ,fail to show an incremental value of psychological ownership in predicting employee performance".

This opens the question about intervening and intermediary variables. Bartkus (1997) identifies only a limited readiness to take on responsibility among US workers. Possible reasons may lie in wrong integration strategies, anxiety about job loss or even in differing interpretations regarding the co-owner role. Poutsma et al. (2006) take into question whether ESO is necessary at all to transform employees' attitudes and behaviour. They assume that in countries where works councils secure a high level of participation rights and commitment ESO may be in vain.

If ESO is expected to provide some positive impacts on company productivity some further measures seem to be necessary. Nerdinger and Martins (2006: 16) argue that "employees with a financial participation also need to be actively involved in the entrepreneurial processes". According to Kaarsemaker and Poutsma (2006: 679) the positive influence of ESO on performance is mainly dependent of a stringent workforce philosophy in which various HRM practices are interconnected and concluded as a whole in order to ,consistently send the message that employees deserve to be owners and that they are taken seriously as such".

This said, the management may also use ESO as a functional substitute for various other forms of participation in order to keep co-operation and commitment high and to secure its freedom in decision-making (Kalmi et al., 2005). Furthermore, ESO can be implemented to weaken existing systems of worker representation or even used as an alternative to them (Ackers et al., 2006).

\section{Peculiarities regarding $C E E$}

The motive to use ESO to encourage entrepreneurial virtues among employees in order to get greater productivity is reflected in the CEE discussion as well, 
however once again in a more indirect way. First of all, a transformation of ownership structures is intended and not a transformation of the employee. But the longer a significant fraction of employees do not sell their shares the more the question occurs whether or not ESO could also lead to higher productivity of firms (Jones and Mygind, 1999, 2000, 2002; Kalmi, 2003). Goic (1999) noted, that to the extent in which ESO can be established as a non-transitional element of the new economic system it will have a sustaining effect on roles, relationships and behaviour of all participants. Other authors, though, rather see a symbolic character of ESO, for instance vis-à-vis of foreign investors (Kalmi et al., 2005; Poutsma et al., 2005).

\subsection{On the way to the firm community - ESO as a means to develop a sense of community}

Another discourse stream focuses on the idea that ESO mainly impacts on the development and fostering of the firm community. While the first discourse stream aimed at resolving some societal problems, this one clearly concentrates on the company level. Herein, a transformation of the employee seems particularly needed - he/she ought to change from a reluctant, selfishly oriented individual into a co-worker who acknowledges the company objectives and subordinates his/her own interests to them. Moreover, it is assumed that the firm community will even thrive on the individual interests and strengths.

\section{Ends and assumed effects}

The aim of the firm community can be found in various forms in the literature. It may be explicitly integrated in concepts such as 'identification', 'partnership' or 'commitment'. The firm community seldom occurs as objective per se but it is mostly considered to positively impact on the fulfilment of the company objectives. Blettner et al. (1995: 12) for instance mention that "the employees need to be better integrated in the company through co-operation in partnership". Voß (2006) points to the opportunity to broaden the fundamental consensus and to strengthen the firm cohesion through ESO. This improved identification would then also lead to a higher sense of responsibility and engagement, a higher work satisfaction, a better cost awareness and, finally, to a higher working time and working cost flexibility (Eyer, 2001; Schuler and Wolff, 2001).

Indeed those forms of participation do only make sense if integrated in a participation-friendly organizational culture. This means: what is to be achieved must already exist, in minimum partly (Maier-Mannhart, 1996). Gollan et al. (2006) postulate a complementarity of forms of financial participation with forms of direct participation.
Thus, ESO should help to develop, via the self concept, a sense of ownership among the employees involved (Rousseau and Shperling, 2003; Pierce and Rodgers, 2004). Schuler and Wolff (2001) also consider this to be an adequate instrument to limit the potential of resistance against entrepreneurial decisions. Moreover, it constitutes an opportunity for social exclusion: "Firm community should provide all participants with a maximum of selffulfilment and, through different forms of involvement and co-determination with co-responsibility, should counter heteronomy" (AGP 2001: §3).

\section{Counter arguments inside the discourse}

Here too, the key problem is that ESO obviously does not imply any simple causality. Even some different long-term studies found no significant correlation between ESO, work satisfaction and commitment (Long, 1978, 1982; Keef, 1998). Kuvaas (2003: 205) sums up: "[T]he idea that ownership in itself, should either automatically or directly generate commitment, seems overly behaviouristic and naïve" (similar Hardwig and Jäger, 1991).

According to those authors there are different reasons for this lack of causality: First, the organisational and societal context of ESO introduction often thwarts the original targets of ESO (Keef, 1998). Furthermore, the motives of employees to buy company shares seem to be based on individual profit calculations (Blettner et al., 1995). Moreover, Long (1978) assumes that the development of a sense of community had to be accompanied by some different forms of immaterial participation. Last but not least, Kuvaas (2003) points to the importance of perceived fairness, particularly regarding the procedural justice of ESO programs.

\section{Peculiarities regarding CEE}

The firm community motive is virtually non-existent in the debate concerned with ESO in the CEE countries. This may be due to the fact that ESO was predominantly considered to be a means to transform the economic order on the (macro-)institutional level (Steger and Šrein, 2006). When taken into account on the company level, ESO was not perceived as an instrumental tool but rather as an indicator of a still existing communitarian spirit among the workforce. This sense of community is traceable in the notion that employees sold their shares to the company management sooner or later (rather than to external investors) which resulted in a widespread "managerial entrenchment" against outsiders (Filatotchev et al., 1999).

\subsection{From employee to co-manager - ESO as a means to balance power inequalities}

This discourse stream discusses the potentials and limits to 
promote the idea of 'having part' in the decision-making process of the company, connected with the topics of codetermination and participation. Thus, ESO stands for the opportunity to deliberatively enlarge co-determination or to take into question and to substitute various classic forms of co-determination. Consequently, the focus lies on transformations on the company level. In a second step, though, the employees' transformation, in direction of a 'zoon politicon' with respect to the organisational micropolitics, is also addressed.

\section{Ends and assumed effects}

If the idea of 'economic participation' through ESO becomes connected with participation in the entrepreneurial process, this also raises several questions about power (distribution) in the company (Steger and Hartz, 2008). Pendleton and Poutsma (2004) point to the fact, that ESO could be interesting from the unions' perspective since it possesses some potential to increase industrial democracy. Buchko (1993) argues that the opportunity to influence and control company decisions would constitute an important variable to model the relationship between ownership and behaviour ( similar Russell et al. 1979). Kauls (2006) even postulates that participation in the company capital must be connected with a higher influence on the company politics - not at last in order to enable the productivity effects expected by the employers (similar FitzRoy and Kraft, 1995). This could also imply the organisation and mobilisation of the employee shareholders (Wheeler, 2008).

\section{Counter arguments inside the discourse}

Several authors argue that ESO would not automatically lead to the modification of the company power balance (Hammer and Stern, 1980; Bartkus, 1997). Steger and Hartz (2008), based on case study evidence, demonstrated that traditional hierarchies usually tend to remain in place. ESO could even bring along a limitation of the classic participatory rights (Pendleton and Poutsma, 2004). Gollan et al. (2006) see ESO to be strongest with respect to productivity and other targets when connected with forms of direct participation. However, this may raise the danger that unions and other forms of indirect participation could be considered obsolete (similar Ackers et al., 2006). Moreover, conflicts were found to arise between (external, non-involved) unionists and (internal, involved) works council members regarding how to interpret ESO (Guski and Schneider, 1983; Steger and Hartz, 2008).

\section{Peculiarities regarding CEE}

The problem of redistribution of organisational power is also reflected in the debate about privatisation in CEE. Many authors initially expected that the employees would rapidly sell their shares to foreign investors in order to fulfil short-term needs of consumption (Aghion and
Blanchard, 1998). It was found, indeed, that employees usually did not retain their shares with the hope to receive higher influence on management decisions (Buck et al. 1998). However, most often employees sold their shares to their own managers (Vaughan-Whitehead, 2003) who merely considered ESO as a vehicle to transform state ownership into management control (Kalmi, 2003). Obviously, the employees do not seem to intend to put the existing distribution of organisational power into question. They rather try to preserve their employment and to secure long-term prospects of regular income by means of a pact with the management.

From a more radical perspective ESO was also considered an attempt to realise some Marxist ideals that had been rather theoretical in the past by transferring the companies into employees' hands (Mygind, 2002). Käppler (1995) for instance discusses these opportunities as a kind of antithesis in contrast to the privatisation policy in the former GDR. Such attempts, however, were massively countered by a widespread de-valuation of all kinds of concepts and ideas assumed to reflect socialist ideology ('no more socialism!') (Steger and Šrein, 2006). Consequently, the re-distribution of organizational power in favour of employees often occurs as ex-post statements in discussions about missed chances in the transformation process.

\subsection{The employee as a final rescue - ESO as a means to privatise and run the company}

Another discourse stream discusses ESO on the background of large-scale societal changes and crisis conditions. ESO, on the one hand, is intended to guarantee a smooth transition from public to private ownership. On the other hand, it takes the role of an instrument to safe struggling companies from bankruptcy, unfriendly take-overs or other crisis-scenarios. In contrast to the other discourse streams the employees appear as an important vehicle for the transformation of the society and/or the overcoming of company crises.

\section{Ends and assumed effects}

Even in the context of Western (OECD member) states, ESO is considered a vehicle to transfer state ownership into private property (Pendleton et al., 1998; Cin et al., 2003). However, in the middle and long run employees are expected not to undergo a transformation themselves but rather to sell their shares, as soon as a good offer of outsiders exists, and thus contribute to the transformation of companies (i.e. restructuring according to common efficiency standards) and markets (i.e. development/ strengthening of both a market for shares and for corporate control) (Mygind, 2002). 
With the help of ESO some further financial targets should be achieved such as a transition to flexible wages (Blasi et al., 1994) or the reduction of tax burdens (Bartkus, 1997; Eyer, 2001). On the company level, the employees may also contribute to overcome some liquidity problems and to safe jobs, particularly in times of crisis (Brinck, 2002). Furthermore, ESO can effectuate an increase of equity capital in order to improve the conditions for necessary investments or to enable them at all (Poutsma et al., 2003; Priewe, 2001). Here, the employees take the role of investors with a long-term perspective entitled to replace unwilling banks or short-term oriented external investors.

One further aspect of this discourse stream is the idea to use ESO as a means to create some strategic ownership in employees' hands. This should help to defend the company against unwelcome external investors ('poison pill') who threat to reduce or to transfer jobs (Dunn, 1989; Leitsmüller and Naderer, 2007). Last but not least, ESO could help to facilitate succession planning, for instance through the option of an employee-buy-out (Buchko, 1993; Eyer, 2001).

\section{Counter arguments inside the discourse}

Critical scholars have challenged the arguments of this discourse stream referring to several problem aspects. Most prominently, it was argued that employees may not behave as expected and may sell their shares to the 'wrong investors', thus consolidating insider ownership (Vaughan-Whitehead, 2003). Particularly during and after the privatisation process the authority of the company management to direct their workforce should not be underestimated. Moreover, some authors also point to the fact that the postulated employee behaviour is hardly rationale. Priewe (2007) for instance questions why it should be reasonable for employees to take a financial risk that is, in the same time, assessed by the market or by bank experts to be too dangerous.

\section{Peculiarities regarding CEE}

Not surprisingly, this discourse stream is the most widespread to be found in CEE countries. Not only for the transformation of companies but also for the transformation of the state as a whole, the employees are considered a stopgap (Aghion and Blanchard, 1998) who should help "to transfer the outcomes of the socialist accumulation into capitalism" (Fülberth, 2006: 289). ESO should secure the legitimacy of this transformation through a broad distribution of ownership (Bogetic, 1993). Moreover, ESO is intended to carefully introduce the employees to the mechanisms of the market economy, to safeguard jobs and, thus, to soften the negative consequences of the transformation (Briam et al., 1997; Pfüller, 2003).

The crucial point of this discourse stream is the particular expectations about employees' long-term behaviour. According to neo-classic prescriptions reported by several Western and domestic experts (Boycko et al., 1996; World Bank, 1996), the employees should sell their shares to (international) investors as soon as they enter the market. The traditional employees' suspicion, it was assumed, would support this behaviour. However, this counter-indicated use of an 'alternative' Western instrument to establish neo-classic structures did not meet the high expectations. On the one hand, ESO did not just constitute a temporary state but was much more widespread and persistent than initially expected (Prasnikar and Gregoric, 2002; Kalmi, 2003). On the other hand, employees behave in a particular neo-classic manner (consumer orientation, job preservation) and usually sold their shares to the company management. Obviously, for the employees in CEE 'a bird in the hand is worth two in the bush' (Aghion and Blanchard, 1998) while the managers have profited from their privileged position during the process of change of ownership structures (Filatotchev et al., 1999).

\subsection{The employee as utility maximiser - ESO as means to foster corporate governance and control}

The final discourse stream includes a rather different actor construction of the employee compared to the previous ones. On the basis of the assumption of an ahistorical, anthropological consistency of human behaviour the employee is perceived as a rational maximiser of personal utility in line with the economic principal. This implies that the employees optimise several variables in parallel - they maximise job security and the accumulation of capital while minimising the necessary input needed. A transformation is predominantly intended at the company level as ESO should help fostering the company's corporate governance and human resource management.

\section{Ends and assumed effects}

First of all, the motive of the maximiser of interests can be found in relation with the employees' individual capital accumulation (Blettner et al., 1995; Keef, 1998). In this context ESO can be considered an instrument among others that is purposefully chosen by the employee to improve his/her capital resources in the short or in the long run (Landesregierung Bayern, 2007). The objective to promote the capital accumulation is also included in the company regulations for the introduction of ESO (Havighorst and Müller, 2003) while the idea to complement the existing pensions is seldom mentioned (Hollender and Scholand, 2002). Unlike the logic of 'having part' the starting point is not a deficit in justice but the calculation of individual interests. Accordingly there also occur some explicit promises about a (luring) return of investment (e.g., Ministerium für Arbeit und Soziales NRW, 2001). 
Well connectable to this discourse stream is the construction of the employee as a shareholder. "Investors and employees alike would gain if companies turned employees into corporate partners by granting stock options to most of the workforce" (Blasi et al. 2003: xi). The calculation of private interests on the side of the employee is also used whenever ESO is addressed as a means to control the performance of workers and to make them perform better (Hübler, 1995). Gollan et al. (2006) point to the opportunity to increase both group pressure and performance pressure with the help of ESO. Pendleton (2006) also considers ESO an adequate reward instrument in combination with pay-for-performance wherever the costs to control individual performance are too high.

If ESO makes part of a modern reward system granting an extra bonus, it can also be considered an important instrument in the 'war for talents' or to secure the long-term commitment of the highly qualified workforce (Eyer, 2001; Bellmann and Leber, 2007). Moreover, the maximisation of influence on entrepreneurial decisions makes also part of this discourse stream. It is assumed that the employees bear an interest in maximising both job security as a source of a calculable income and participation in the sense of a co-operatively led company (Kaarsemaker and Poutsma, 2006). In this context, the employee is considered to be able to maximise some conflicting interests at the same time.

\section{Counter arguments inside the discourse}

Several authors seriously question whether ESO is a feasible means for the individual capital accumulation. Hollender and Scholand (2002) point to the complex calculation of risk in the context of the envisaged pensions. Others warn about the double risk of losing both job and funds at the same time (Kauls, 2006; SPD, 2007). Ehrhart (2007) adds that the attraction of ESO would be limited by the marketability of the shares, the increased costs of a job change and the potentially increased reward insecurity. Furthermore, the potential of ESO to enable employees' participation in the increase of capital incomes is questioned - given the various alternative instruments (Bundestagsfraktion Bündnis 90/Die Grünen, 2006).

Moreover, there also occurs a certain collision between the objectives of an individual capital accumulation on the one hand and of an entrepreneurial employee on the other, for instance regarding the question about wage sacrifices. The rationally calculable security of pensions runs counter to the performance incentives of ESO that are connected with an individually attributable risk.

\section{Peculiarities regarding CEE}

In the debate about ESO in CEE employees are regularly perceived as maximisers of capital for more or less longterm consumption needs making rational calculations about financial gains, income losses and the transaction costs of job changes (Aghion and Blanchard, 1998). However, some particular potential conflicts do also occur. On the one hand, actor constructions as the utility maximisers run counter to some widely propagated 'good citizen'expectations (cf. section 3.5). Also from the perspective of business ethics, it is questioned whether ESO in this respect may promote a learning process that results in a 'mass-production' of 'neo-classic-style capitalists'. The most recent global financial crisis has highlighted the downsides of such a development.

\subsection{The dominant actor constructions of the employee in the ESO discourse}

Against the background of the six discourse streams we are able to reconstruct the various actor models of the employee that implicitly exist in the narrations about ESO. From a formal perspective, the employee becomes a shareholder through ESO. Thus, ESO introduces a social innovation into the economic realm that, on the one hand, the ESO discourse has tried to describe and comprehend using the vocabulary of means-end relations with reference to causes, subsequent effects and associated problems. In order to account for the missing knowledge about the employees' preferences and attitudes towards ESO, the ESO discourse, on the other hand, resorts to already familiar categories of typical economic actors rooted in some semantic lead differences, namely productionconsumption, capital-labour, and ownership-control.

Beside this, to provide the employees of a company with company shares provokes a kind of before-after or target-performance comparison respectively on different levels, be it the society, the company or the employee. In most of the ESO discourse a transformation of the employee is intended and, consequently, the target-images about the employee holding company shares prevail. Those target-images are based on different kinds of pictures of the entrepreneur or the shareholder respectively. A naïve observer might expect that a transition of the employee will take place in the narrations, moving from a state that has to be overcome to an aspiring target state. This would imply that the employee undergoes a transition from one value of the underlying semantic lead distinctions to the opposite value within this distinction, e.g. from proletarian to capitalist in the form of either an entrepreneur, coowner, or shareholder etc. However, such a transition would confront the discourse with the general problem to consider the employee simultaneously as a worker and a capitalist, an employee and a shareholder, or a worker and a manager. This semantic reshaping of the employee includes coming to terms with the very contradictions that are unavoidably connected to those hybrids when measured against traditional notions of the conflict between capital and labor or ownership and control. Our finding is that, contrary to this naïve expectation, the discourse streams 
usually avoid such a transition of the employee in order to avoid obvious contradictions and paradoxes. The different discourse streams handle this problem - to conceal a paradox - rather differently.

If ESO appears as a vehicle to reconcile some societal subgroups (discourse stream 1) the employee becomes a worker-shareholder who has to be grateful for having received a share of capital and who is, therefore, ready to remain a worker, to enjoy the advantages of his/her shares and to renounce on using his/her new position as a means to initiate conflicts or to enlarge co-determination. If ESO is intended first of all to support the firm community (discourse stream 3 ) the employee appears as an actor who gratefully reacts to the paternalistic inputs of the company management, too. Though, in this case there is a more individualistic touch to the employee insofar as he/she is expected not only to renounce on adversarial actions against the management but also to provide some active (creative, innovative) extra-contributions in favour of the company. In the discussion about the entrepreneurial activation of the employee (discourse stream 2) the contradiction of the worker-capitalist is mitigated by two restrictions. First, he/she is considered to be a co-entrepreneur only in the narrow confines of his/her workplace. Second, no one in the discourse usually expects an average small shareholder to become an entrepreneur. The concept of the employee as a workplace-entrepreneur appears to be a management concept prescribing entrepreneurship with homeopathic dosage. The idea of the worker-shareholder (discourse stream 4) is somewhat contradictory, too. Here, the contradiction resides in the fact that some controlled workers, through ESO, may control the same managers who are entitled to control them. Therefore, the ESO is rather thought as a management tool to control the employees more subtly and more efficiently.

The target-concepts of the employee that we have discussed up to now have to be understood against the background of images of the actual state of the employees that has to be overcome. Although these images are hardly mentioned the metaphor of the employee as a stopgap (discourse stream 5) renders one image rather obvious. For example, the precondition for the employee to become a multi-functional 'sheet anchor' in the transformation process of the CEE countries is that he/she perceives the economy from the standpoint of a consumer with stable preferences that can be realised with the help of ESO. In all the narrations of the employee as a stopgap (employees holding ESO as a 'poison pill', as capital provider in times of crisis, or as supporters of privatisation in OECD and CEE states) a transformation of the employees through ESO was not intended at all.

To sum up, we can identify at least five actor models within the ESO discourse:

1) the employee who identifies with the enterprise goals, remaining bound to workplace and hence under management-control but who is more or less activated by better prospects of consumption (discourse streams 1 to 3 );

2) the employee with extended possibilities for representative participation in order to better secure interests in participation in consumption (discourse stream 4);

3) the consumption-oriented jobholder with short as well as long-term preferences (discourse stream 5);

4) the jobholder who is at the same time a consumptionoriented hobby equity-holder optimizing his/her portfolio (discourse stream 6);

5) the entrepreneurially activated employeeshareholder who unifies ownership and control (the "self-managed, self-employed" employee of the high performance work system literature) (discourse streams 2 and 4).

Table 1 summarises the key characteristics of the six discourse streams.

\section{Discussion}

In our paper, we challenged the knowledge deficit regarding the employees' perspectives on ESO by carrying out a semantic analysis of a substantial portion of respective literature with in order to identify the various actor constructions used implicitly in the ESO discourse.

Let us sum up our findings with respect to the link between the surface of the ESO discourse and its underlying semantic structure. Whereas on the surface of the ESO discourse one can identify at least six streams defined by the purposes for which an ESO is used for, at the level of the underlying structure we can also identify three semantic lead distinctions organizing the discourse and providing connectivity to the contributions and positions within it. The organizing power of the semantic lead distinctions can be highlighted in two ways. First, we accounted for the link between the purposes of an ESO, the actor models for the employee, and the underlying semantic lead distinctions. Second, we provided evidence for the fact that the discourse's dynamic is co-determined by the necessity to avoid some obvious paradoxes that occur because the shareholding employee is often portrayed as a social role that combines some defining characteristics considered to be contradictory in the light of those semantic lead distinctions. More concretely, we could identify in minimum five actor models of the employee communicatively constructed in the discourse. Interestingly, in most of the discourse streams the shareholding employee is implicitly pictured as a consumer with stable preferences, despite the fact that on formal grounds the same discourse streams explicitly maintain that the shareholding employee may become an entrepreneur, co-owner or controller of management. 
Table 1: Key characteristics of the six discourse streams

\begin{tabular}{|c|c|c|c|}
\hline & Means and ends & Problems & Transitions \\
\hline $\begin{array}{l}\text { Out of capital and labour } \\
\text { (3.1) }\end{array}$ & $\begin{array}{l}\text { - Reconciliation of antagonis- } \\
\text { tic societal groups } \\
\text { - Fairer distribution of nation- } \\
\text { al income }\end{array}$ & $\begin{array}{c}\text { - Reconciliation as a mere } \\
\text { social romanticism } \\
\text { - Double risk for employ- } \\
\text { ee-owners } \\
\text { - Income substitution instead } \\
\text { of increase in wealth }\end{array}$ & $\begin{array}{c}\text { - Primarily state level } \\
\text { - Secondary individual level }\end{array}$ \\
\hline $\begin{array}{l}\text { From employee to co-owner } \\
\qquad(\mathbf{3 . 2 )}\end{array}$ & $\begin{array}{c}\text { - Activating the employee } \\
\text { - Promotion of entrepreneurial } \\
\text { habitus and entrepreneurial } \\
\text { virtues }\end{array}$ & $\begin{array}{l}\text { - Very limited share of total } \\
\text { equity capital } \\
\text { - Limited entrepreneurial } \\
\text { experience } \\
\text { - ESO as a means to abduct } \\
\text { employees from the unions } \\
\text { influence }\end{array}$ & $\begin{array}{l}\text { - Primarily individual level } \\
\text { - Secondary enterprise level }\end{array}$ \\
\hline $\begin{array}{l}\text { On the way to the firm com- } \\
\text { munity (3.3) }\end{array}$ & $\begin{array}{l}\text { - Developing a sense of com- } \\
\text { munity } \\
\text { - Promotion of responsibility } \\
\text { and engagement }\end{array}$ & $\begin{array}{l}\text { - Idea of ownership automati- } \\
\text { cally generating of commit- } \\
\text { ment rather naïve } \\
\text { - Reverse causality? } \\
\text { - Individual motives of em- } \\
\text { ployees? }\end{array}$ & $\begin{array}{l}\text { - Primarily individual level } \\
\text { - Secondary enterprise level }\end{array}$ \\
\hline $\begin{array}{l}\text { From employee to co-manager } \\
\qquad(\mathbf{3 . 4 )}\end{array}$ & $\begin{array}{c}\text { - Redistribution of power } \\
\text { - Promotion of organizational } \\
\text { democracy } \\
\text { - Promotion of a solidary } \\
\text { economy }\end{array}$ & $\begin{array}{c}\text { - Lack of causality } \\
\text { - Substitution of existing } \\
\text { co-determination }\end{array}$ & $\begin{array}{l}\text { - Primarily enterprise level } \\
\text { - Secondary individual level }\end{array}$ \\
\hline $\begin{array}{c}\text { The employee as a final res- } \\
\text { cue (3.5) }\end{array}$ & $\begin{array}{l}\text { - Supporting a smooth transi- } \\
\text { tion from public to private } \\
\text { ownership } \\
\text { - Coping with company finan- } \\
\text { cial crises }\end{array}$ & $\begin{array}{c}\text { - Resilience of ,insider own- } \\
\text { ership“ } \\
\text { - Risk-averse behaviour } \\
\text { - Authority of the company } \\
\text { management during/after } \\
\text { privatisation }\end{array}$ & $\begin{array}{l}\text { - Primarily enterprise level } \\
\text { - Partly also state level }\end{array}$ \\
\hline $\begin{array}{c}\text { The employee as maximiser } \\
\text { of private interest (3.6) }\end{array}$ & $\begin{array}{l}\text { - Fostering corporate gover- } \\
\text { nance and human resource } \\
\text { management } \\
\text { - Improving employees' indi- } \\
\text { vidual wealth }\end{array}$ & $\begin{array}{l}\text { - Complex calculation of risk } \\
\text { (regarding retirement pro- } \\
\text { vision) } \\
\text { - Individual vs. company } \\
\text { wealth maximization }\end{array}$ & - Enterprise level \\
\hline
\end{tabular}

Thus, the implied actor models rather remain on the side of labour within the capital-labour-distinction. In other words, the discourse streams usually avoid picturing a radical transformation of the shareholding employee who becomes a capitalist while still remaining a worker.

Regarding CEE, we can conclude our findings in three points: First, the ESO discourse in CEE differ significantly from the Western mainstream on the 'surface order', most probably due to some very different starting conditions in those countries in 1989 (e.g., low level of private ownership, specific capital-labour distinction). This resulted in some rather differing accentuations of discourse streams (e.g., very strong discourse stream 5, weak 2, 3). Moreover, some obvious re-interpretations of Western experiences occur - while ESO is traditionally considered an effective means to avoid external investors, it was employed in the CEE context to facilitate them, while ESO is traditionally perceived as an alternative to overcome capitalism towards socialism, it was comprehended in the CEE context as a second best means to overcome socialism towards capitalism.

Second, the ESO discourse in CEE is much more politicised compared to Western experiences. Transformation(s) on the state level and the concept of the 'good citizen' dominate in the debate. Obviously, questions about the political legitimation of the privatisation process are much more important than aspects of economic efficiency.

Third, unlike the 'surface order', where the employee is explicitly addressed as zoon politicon and state citizen for reasons of political legitimacy of the transformation process, the 'underlying order' of the ESO discourse in CEE is fairly in line with the Western mainstream. It uses the same lead distinctions and concludes the same 
actor models as those described above, thus stressing the consumer orientation of the Eastern employees.

Some limitations of our paper (and implications for future research) need to be mentioned: First, our discourse analysis about CEE is somewhat limited as the native language literature was excluded. It can be assumed that some specific aspects that are not discussed here may arise there. Nevertheless, it is interesting, also for the political and economic actors in CEE to see how the ESO debate in CEE is constructed on an international level. Second, some cross-national comparative studies could examine the role of different discourse streams and actor constructions in different capitalist orders and how they are interrelated with different (historical) paths. This may help to overcome national bias and to detect some further types of discourse streams, actor constructions, or lead distinctions beyond our findings. Third, we focused on discourses and narrations and not on the concrete decisions made by individuals, companies, governments, or institutions etc. So, the discourse may reflect practice but is not equal with practice. Further work is needed to clarify this difference. Fourth, researchers may distinctively explore the correlations between different empirical narrator positions, i.e. authors of the discourse, with different discourse streams and different constructions of the employee. This would enable us to distinguish the political character of the discourse in more detail. Fifth, our analysis demonstrates that 'the' employee as a clearly identifiable entity does not seem to exist, apart from its construction. The re-construction of those processes by which images of the shareholding employee are constructed takes place under the same conditions as these processes themselves. Consequently, any attempts to look behind the curtain of the discourse and to detect the 'real' employee must be treated with great care.

\section{Literature}

Ackers, P., Marchington, M., Wilkinson, A., \& Dundon, T. (2006). Employee participation in Britain. Decision, 33(1), 75-88.

Aghion, P., \& Blanchard, O.J. (1998). On privatization methods in Eastern Europe and their implications. Economics of Transition, 6(1), 87-99, http://dx.doi. org/10.1111/j.1468-0351.1998.tb00038.x

AGP (2001). Vereinssatzung. Retrieved 23.10.2008 from http://www.agpev.de/agpueberuns/satzung/index.html

Armstrong, R. (1982). KME: The Life of a Co-operative. Employee Relations, 4(1), 17-21.

Bartkus, B.R. (1997). Employee ownership as catalyst of organizational changes. Journal of Organizational Change Management, 10(4), 331-344, http://dx.doi. org $/ 10.1108 / 09534819710175857$

Bellmann, L., \& Leber, U. (2007). Materielle Mitarbeiterbeteiligung. IAB Kurzbericht, 13, 1-6.
Bispinck, R., \& Brehmer, W. (2008). Kapitalbeteiligung und Bezahlung nach Gewinn. WSI Mitteilungen, 61(6), 312-320.

Blasi, J., Gasaway, J., \& Kruse, D. (1994). Employees and managers as shareholders. Human Resource Planning, 17(4), 57-67.

Blasi, J., Kruse, D., \& Bernstein, A. (2003). In the company of owners. New York: Basic Books.

Blettner, K., Heitz, F., \& Wegenaer, D. (1995). MitarbeiterKapitalbeteiligung in Klein- und Mittelbetrieben. Gifhorn: Heizmann.

Bogetic, Z. (1993). The role of employee ownership in privatisation of state enterprises in Eastern and Central Europe. Europe-Asia Studies, 45(3), 463-482, http:// dx.doi.org/10.1080/09668139308412101

Boycko, M., Shleifer, A., \& Vishny, R.W. (1996). A theory of privatisation. Economic Journal, 106(435), 309319, http://dx.doi.org/10.2307/2235248

Briam, K.-H., Schlecht, O., Schneider, H.J., Kötter, P.M., Schleiter, A., Fischer, H., Wulfmeyer, W., Wagner, K.-R., \& Leber, G. (1997). Mitarbeiter am Kapital beteiligen. Gütersloh: Bertelsmann.

Brinck, S. (2002). Mitarbeiterbeteiligung - Ein Weg zu höherer Produktivität, Innovation, Beschäftigung und Rentabilität. Kassel: AGP.

Bröckling, U. (2007). Das unternehmerische Selbst. Frankfurt: Suhrkamp.

Buchko, A. (1993). The effects of employee ownership on employee attitudes. Journal of Management Studies, 30(4), 633-657, http://dx.doi. org/10.1111/j.1467-6486.1993.tb00319.x

Buck, T., Filatotchev, I., \& Wright, M. (1998). Agents, stakeholders and corporate governance in Russian firms. Journal of Management Studies, 35(1), 81-104, http://dx.doi.org/10.1111/1467-6486.00085

Bundestagsfraktion Bündnis 90/Die Grünen (ed.) (2006). Vom Mitarbeiter zum Mitunternehmer - Mehr Teilhabe durch Mitarbeiterbeteiligung? Dokumentation des Fachgesprächs Mitarbeiterbeteiligung vom 4.7.2006 in Kassel. Retrieved 30.10.2008 from http://www. gruene-bundestag.de

Cin, B., Han, T., \& Smith, S.C. (2003). A tale of two tigers: Employee financial participation in Korea and Taiwan. International Journal of Human Resource Management, 14(6), 920-941, http://dx.doi.org/10.108 $\underline{0 / 0958519032000106146}$

Collom, E. (2003). Two classes and one vision? Managers ' and workers ' attitudes toward workplace democracy. Work and Occupation, 30(1), 62-96, http://dx.doi. org $/ 10.1177 / 0730888402239327$

Dobák, M., \& Steger, T. (2003). Corporate Governance in Central and Eastern Europe - An introductory review. Journal for East European Management Studies, 8(3): 223-235.

Dunn, C.P. (1989). ESOPs: The 'Trojan Horse' of the antitakeover realm. Business Horizons, 32(4), 28-35, 
http://dx.doi.org/10.1016/0007-6813(89)90054-2

Edwards, V., \& Lawrence, P. (2000). Management in Eastern Europe. Basingstoke: Palgrave.

Ehrhart, N. (2007). Mitarbeiterkapitalbeteiligung: Ansatzpunkte für eine eventuelle staatliche Unterstützung. Paper presented in the ESO-working group of the German Union Association in Berlin, 21 June.

Eyer, E. (2001). Vom Mitarbeiter zum Mitunternehmer durch Kapitalbeteiligung. Arbeit und Arbeitsrecht, 56(11), 498-502.

Fiedler-Winter, R. (2000). Innovative Mitarbeiterbeteiligung: Der Königsweg für die Wirtschaft (2. ed.). Landsberg: Moderne Industrie.

Filatotchev, I., Wright, M., \& Bleaney, M. (1999). Privatization, insider control and managerial entrenchment in Russia. Economics of Transition, 7(2), 481-504, http://dx.doi.org/10.1111/1468-0351.00022

FitzRoy, F.R., \& Kraft, K. (1995). On the choice of incentives in firms. Journal of Economic Behavior \& Organization, 26(1), 145-160, http://dx.doi. org/10.1016/0167-2681(94)00066-N

Foucault, M. (1973). The birth of the clinic: An archaeology of medical perception. London: Routledge.

Fülberth, G. (2006). G Strich - Kleine Geschichte des Kapitalismus. Cologne: Papyrossa.

Gaugler,E. (2001). Mitunternehmerin der mittelständischen Wirtschaft. Personal, 53(6), 430-435.

Goic, S. (1999). Employees' attitudes towards employee ownership and financial participation in Croatia. Journal of Business Ethics, 21(2/3), 145-155, http:// dx.doi.org/10.1023/A:1006288808755

Gollan, P. J., Poutsma, E., \& Veersma, U. (2006). Editors' introduction - New roads in organizational participation? Industrial Relations, 45(4), 499-512, http://dx.doi.org/10.1111/j.1468-232X.2006.00441.x

Gurdon, M. A. (1991). The politics of property in the Federal Republic of Germany. International Labour Review, 130(5-6), 595-611.

Guski, H.-G., \& Schneider, H.J. (1983). Betriebliche Vermögensbeteiligung in der Bundesrepublik Deutschland, Teil II: Ergebnisse, Erfahrungen und Auswirkungen in der Praxis. Cologne: Deutscher Instituts-Verlag.

Hammer, T. H., \& Stern, R.N. (1980). Employee ownership implication for the organizational distribution of power. Academy of Management Journal, 23(1), 78100, http://dx.doi.org/10.2307/255497

Hardes, H.-D., \& Wickert, H. (2004). Praxisbeispiele zur Erfolgs- und Kapitalbeteiligung der Mitarbeiter. Munich: Hampp.

Hardwig, T., \& Jäger, W. (1991). Selbstverwaltung im Betrieb. Wiesbaden: Gabler.

Hartz, R., Kranz, O., \& Steger, T. (2009). Der Arbeitnehmer im Diskurs der Mitarbeiterkapitalbeteiligung eine semantische Sekundäranalyse. Industrielle
Beziehungen, 16(4), 327-348, http://dx.doi. org/10.1688/1862-0035 IndB 200904 Hartz

Havighorst, F., \& Müller, S. G. (2003). Mitarbeiterkapitalbeteiligung: Analyse und Handlungsempfehlungen. Frankfurt: Bund.

Hofmann, H., \& Munz, S. (2002). Verbreitung von Mitarbeiter-Kapitalbeteiligungen und von Vorkehrungen zum Insolvenzschutz für mit vermögenswirksamen Leistungen erworbenen Kapitalbeteiligungen. Berlin: Bundesministerium für Arbeit und Sozialordnung.

Hofmann, I., Leitsmüller, H., \& Naderer, R. (1993). Betroffene melden sich zu Wort - die Meinung der Arbeitnehmer zur Mitarbeiterbeteiligung. In I. Hofmann, A. Kraus, H. Leitsmüller, \& R. Naderer (Eds.), Arbeitnehmer als Eigentümer (pp. 70-104). Wien: Orac.

Höge, T. (2006). Mitarbeiterbeteiligungen. Zum Stand der Forschung zu den psychologischen Faktoren. Arbeit, 15(4): 246-258.

Hollender, O., \& Scholand, M. (2002). Aktienbeteiligungen der Arbeitnehmer als Bestandteil der privaten Altersvorsorge. Kreditwesen, 9, 17-20.

Huber, B. (2006). Investivlohn einführen? Freie Presse, 22. Dez.

Hübler, O. (1995). Produktivitätssteigerung durch Mitarbeiterbeteiligung in Partnerschaftsunternehmen? Mitteilungen aus der Arbeitsmarkt- und Berufsforschung, 28(2), 214-223.

Jones, D. C., \& Mygind, N. (1999): The nature and determinants of ownership changes after privatization: Evidence from Estonia. Journal of Comparative Economics, 27(3), 422-441.

Jones, D. C., \& Mygind, N. (2000). The effects of privatization on productive efficiency: evidence from the Baltic Republics. Annals of Public and Cooperative Economics, 71(3), 415-439, http://dx.doi. org/10.1111/1467-8292.00147

Jones, D. C., \& Mygind, N. (2002). Ownership and productive efficiency: Evidence from Estonia. Review of Development Economics, 6(2), 284-310, http:// dx.doi.org/10.1111/1467-9361.00154

Kaarsemaker, E., \& Poutsma, E. (2006). The fit of employee ownership with other human resource management practices. Economic and Industrial Democracy, 27(4), 669-685, $\quad$ http://dx.doi. org/10.1177/0143831X06069009

Kalmi, P. (2003). The rise and fall of employee ownership in Estonia, 1987-2001. Europe-Asia Studies, 55(8), 1213-1239, http://dx.doi.org/10.1080/0966813032000 $\underline{141097}$

Kalmi, P., Pendleton, A., \& Poutsma, E. (2005). Financial participation and performance in Europe. Human Resource Management Journal, 15(4), 54-67, http:// dx.doi.org/10.1111/j.1748-8583.2005.tb00295.x

Käppler, S. (1995). Alternative Wirtschaftskonzeptionen 
zur Strategie einer radikalen Privatisierung. In W. Dümcke \& F. Vilmar (Eds.), Kolonialisierung der DDR - kritische Analysen und Alternativen eines Einigungsprozesses (170-188), Münster: agenda.

Kauls, H. (2006). Mitbestimmung und materielle Mitarbeiterbeteiligung. Working paper of the German Union Association. Berlin.

Keef, S. P. (1998). The causal association between employee share ownership and attitudes. British Journal of Industrial Relations, 36(1), 73-82, http:// dx.doi.org/10.1111/1467-8543.00080

Kruse, D. L., Blasi, J. R., \& Park, R. (2008). Shared capitalism in the U.S. economy? Prevalence, characteristics, and employee views of financial participation in enterprises. NBER Working paper, 14225. Cambridge.

Kuvaas, B. (2003). Employee ownership and affective organizational commitment. Scandinavian Journal of Management, 19(2), 193-212, http://dx.doi. org/10.1016/S0956-5221(01)00044-6

Köhler, H. (2007). Berliner Rede 2007. Retrieved 30 April 2016 from http://www.bundespraesident. de/SharedDocs/Reden/DE/Horst-Koehler/ Reden/2007/10/20071001 Rede.html

Landesregierung Bayern (Ed.) (2007). Fit durch Mitarbeiterkapitalbeteiligung (3rd ed.). Retrieved 30.10.2008 from http://www.agpev.de/

Leitsmüller, H., \& Naderer, R. (2007): Mitarbeiterbeteiligung: Motive - Modelle - Risiken Tipps. Vienna: AK.

Lezius, M. (2004). Geldbörse wichtigster Körperteil des Menschen. Arbeitgeber, 5, 24-25.

Liu, N.-C., Lin, A., \& Lin, C.-H. (2009). Why do employees hold their vested stocks while they can sell them? International Journal of Human Resource Management, 20(1), 148-163, http://dx.doi. org/10.1080/09585190802528532

Long, R.J. (1978): The effects of employee ownership on organizational identification, employee job attitudes, and organizational performance. Human Relations, 31(1): 29-48, http://dx.doi. org/10.1177/001872677803100102

Long, R. J. (1982). Worker ownership and job attitudes. Industrial Relations, 21(2), 196-215, http://dx.doi. org/10.1111/j.1468-232X.1982.tb00228.x

Luhmann, N. (1989). Die Wirtschaft der Gesellschaft. Frankfurt: Suhrkamp.

Maier-Mannhart, H. (Ed.) (1996). Mitarbeiterbeteiligung: vom Mitarbeiter zum Mitunternehmer. Munich: Olzog.

Mathieu, M. (2006). The European employee ownership top 100. Brussels: EFES.

Ministerium für Arbeit und Soziales des Landes NordrheinWestfalen (2001). Mitarbeiterkapitalbeteiligung in Nordrhein-Westfalen. Dusseldorf.

Mišić, B. (1998): Employee share ownerhsip and the transformation of property: The Slovene experience.
South-East Europe Review, 1(3), 81-88.

Mygind, N. (2002). The role of different ownership structures for restructuring. CEES Working paper, 45. Copenhagen: CBS.

Mygind, N. (2012). Trends in employee ownership in Eastern Europe. International Journal of Human Resource Management, 23(8), 1611-1642, http:// dx.doi.org/10.1080/09585192.2012.661992

Nerdinger, F.W., \& Martins, E. (2006): Teilhabe an Entscheidungen wirkt positiv. Kapitalbeteiligung und ihre psychologischen Wirkungen. Ratio, 12(5), 16-17.

Pendleton, A. (2006). Incentives, monitoring, and employee stock ownership plans. Industrial Relations, 45(4): 753-777, http://dx.doi.org/10.1111/j.1468232X.2006.00450.X

Pendleton, A., \& Poutsma, E. (2004). Financial participation. The role of governments and social partners. Luxembourg: Office for official publications of the European Communities.

Pendleton, A., McDonald, J., \& Robinson, A. (1995). The impact of employee share ownership plans in employee participation and industrial democracy. Human Ressource Management Journal, 5(4): 44-60, http://dx.doi.org/10.1111/j.1748-8583.1995.tb00382.x

Pendleton, A., Wilson, N., \& Wright, M. (1998). The perception and effects of share ownership. British Journal of Industrial Relations, 36(1): 99-123, http:// dx.doi.org/10.1111/1467-8543.00082

Pfüller, B. (2003). Warum kaufen wir uns nicht selbst? Mitbestimmung, 49(4), 25-29.

Pierce, J.L., \& Rodgers, L. (2004). The psychology of ownership and worker-owner productivity. Group \& Organization Management, 29(5), 588-613, http:// dx.doi.org/10.1177/1059601103254270

Pollert, A. (1999). Transformation at work, London: Sage.

Poutsma, E. (2001). Jüngste Entwicklungstendenzen bei der finanziellen Beteiligung der Arbeitnehmer in der Europäischen Union. Dublin: Europäische Stiftung zur Verbesserung der Lebens- und Arbeitsbedingungen.

Poutsma, E., de Nijs, W., \& Dooreward, H. (1999). Promotion of Employee Ownership and Profit Sharing in Europe. Economic and Industrial Democracy, 20 (2), 171-196, http://dx.doi. org $/ 10.1177 / 0143831 X 99202002$

Poutsma, E., \& de Nijs, W. (2003). Broad-based employee financial participation in the European Union. International Journal of Human Resource Management, 14(6), 863-892, http://dx.doi.org/10.108 0/0958519032000106128

Poutsma, E., Hendrickx, J., \& Huijgen, F. (2003). Employee participation in Europe: In search of the participative workplace. Economic and Industrial Democracy, 24(1), 45-76, http://dx.doi.org/10.1177/0 $\underline{143831 X 03024001599}$

Poutsma, E., Ligthart, P., \& Schouteten, R. (2005). Employee share schemes in Europe. The influence of 
US multinationals. Management Revue, 16(1), 99-122. Poutsma, E., Albaraccin, D., Kalmi, P., Pendleton, A., Trebucq, S., \& Voss, E. (2006). Changing patterns of employee financial participation in Europe. A survey among listed firms in six European member states. Final Report. Nijmegen: Radboud-University.

Poutsma, E., \& Rondeel, F. (2006). Complementarities of financial participation and other forms of participation. Workshop report. Nijmegen: Radboud-University.

Prasnikar, J., \& Gregoric, A. (2002). The influence of workers' participation on the power of management in transitional countries. Annals of Public and Cooperative Economics, 73(2), 269-297, http://dx.doi. org/10.1111/1467-8292.00194

Priewe, J. (2001). Vom Lohnarbeiter zum Shareholder? Prokla, 31(1), 103-122.

Priewe, J. (2007). Vom Arbeitnehmer zum Mitunternehmer? Überschätzte Wirkungen von Kapital- und Gewinnbeteiligungen. WSI Mitteilungen, 60(12), 678-684.

Rousseau, D. M., \& Shperling, Z. (2003). Pieces of the action: Ownership and the changing employment relationship. Academy of Management Review, 28(4), 553-570, $\quad \underline{\text { http://dx.doi.org/10.5465/ }}$ AMR.2003.10899368

Russell, R., Hochner, A., \& Perry, S. (1979). Participation, influence, and worker-ownership. Industrial Relations, 18(3), 330-341, $\quad$ http://dx.doi.org/10.1111/j.1468232X.1997.tb00932.x

Schätzle, R.J. (1996). Aktien für Arbeit. Neue Wege der Mitarbeiter-Beteiligung in Deutschland. Personalführung, 29(8), 680-683.

Schneider, H.J. (1996). Mitarbeiter als Mitgesellschafter. Die materielle Sicht des Mitunternehmers. Personal, 48(3), 112-116.

Schuler, G., \& Wolff, K. (2001). Durch Partnerschaft zum Erfolg - Das Beteiligungsmodell der Homag $A G$. In ifm Mannheim (Ed.), Vom Mitarbeiter zum Mitunternehmer (pp. 9-17). Grüne Reihe 45. Mannheim.

SPD(Ed.)(2007).Deutschlandfonds für Arbeitnehmerinnen und Arbeitnehmer. Berlin.

Steger, T., \& Hartz, R. (2008). The power of participation? - Power relations and processes in employee-owned companies. Zeitschrift für Personalforschung, 22(2), 152-170.

Steger, T. \& Šrein, Z. (2006): Mitarbeiterkapitalbeteiligung in Sachsen und Tschechien - Einblicke in ein heikles Thema. In R. Holeckova, A. Neubert, \& T. Steger (Eds.), Sächsisch-tschechische Unternehmenskooperation - Probleme und Chancen (pp. 43-51). Munich: Hampp.

Van Dyne, L., \& Pierce, J.L. (2004). Psychological ownership and feelings of possession. Journal of Organizational Behavior, 25(4), 439-459, http:// dx.doi.org/10.1002/job.249
Vaughan-Whitehead, D.C. (2003). EU enlargement versus social Europe? Cheltenham: Elgar.

Vickerstaff, S. A., \& Thirkell, J. E. M. (2000). Instrumental rationality and European integration: Transfer or avoidance of industrial relations institutions in Central and Eastern Europe. European Journal of Industrial Relations, 6(2), 237-251, http://dx.doi. org/10.1177/095968010062007

Voß, W. (2006). Materielle Mitarbeiterbeteiligung. Düsseldorf: Hans-Böckler-Stiftung.

Wagner, K.-R. (Ed.) (2002). Mitarbeiterbeteiligung - Visionen für eine Gesellschaft von Teilhabern. Wiesbaden: Gabler.

Wheeler, N. H. (2008). A new frontier for labor. Collective action by worker owners. Labor Studies Journal, 33(2): 163-178, http://dx.doi. org/10.1177/0160449X07302730

World Bank (Ed.) (1996). World Development Report. From plan to market. Washington.

Wright, M., Buck, T., \& Filatotchev, I. (2002). Postprivatization effects of management and employee buyouts. Annals of Public and Cooperative Economics, 73, 303-352, http://dx.doi.org/10.1111/1467-8292.00195

Olaf Kranz is Assistant Professor of Leadership and Organization at the University of Regensburg (Germany). He studied Sociology and Political Sciences at Martin-Luther-University of Halle (Germany) and at Edinburgh University (UK) and earned a PhD from Martin-Luther-University of Halle. His current research interests include theories of organization, the sociology of professions and management consulting, with particular focus on the micro-foundations of everyday organizational life.

Thomas Steger is Professor of Leadership and Organization at the University of Regensburg (Germany). He graduated in Business Administration and Economics at the University of Fribourg (Switzerland) and earned a PhD from Chemnitz University of Technology (Germany). $\mathrm{He}$ also serves as editor-in-chief of the Journal of East European Management Studies (JEEMS). His current research interests include corporate governance and employee ownership with particular focus on the transforming countries of Central and Eastern Europe.

Ronald Hartz is an independent researcher. He graduated in Business Administration at the University of Leipzig (Germany) and earned a PhD from Chemnitz University of Technology. His research interests include alternative forms of work and organization, discourse analysis, and critical management studies. 